Studia Judaica 24 (2021), nr 2 (48), s. 407-435

doi:10.4467/24500100STJ.21.017.15072

Natasza Styrna (iD) https://orcid.org/0000-0002-8368-5863

\title{
Malarki, rzeźbiarki i graficzki z krakowskiego Zrzeszenia Żydowskich Artystów (1931-1939)
}

\author{
WOMEN PAINTERS, SCULPTORS AND GRAPHIC ARTISTS \\ FROM THE KRAKÓW ASSOCIATION OF JEWISH ARTISTS, 1931-1939
}

\begin{abstract}
Eleven women belonged to the Kraków Association of Jewish Artists, active in the 1930s. They dealt with painting, graphic art and sculpture. Unfortunately, not much has survived from their achievements. One of the most interesting artistic personalities in this group was Henryka Kernerówna, educated in Vienna. From 1918 on, female artists younger than her could benefit from studies at the Academy of Fine Arts in Kraków. In the reviews of the exhibitions of the Association, the gender of artists was rarely mentioned, except in some cases. The artists also belonged to other non-Jewish art groups. Most of them survived the war, but none of them remained in Kraków. Three of them were killed.
\end{abstract}

Keywords: women, art, Kraków, interwar period.

Słowa kluczowe: kobiety, sztuka, Kraków, okres międzywojenny.

\section{Wstęp}

Środowisko artystów żydowskich w Krakowie zaczęło się konsolidować u schyłku lat dwudziestych XX w. Pierwszą organizacją skupiającą jego przedstawicieli było Żydowskie Towarzystwo Krzewienia Sztuk Pięknych założone w połowie 1929 r. ${ }^{1}$ Po ponad dwu latach, gdy zaczęła wygasać jego działalność, twórcy żydowscy w mieście powołali do życia kolejną organizację - Zrzeszenie Żydowskich Artystów Malarzy i Rzeźbiarzy.

${ }^{1}$ Dziś organizacyjne zebranie Żydowskiego Towarzystwa Krzewienia Sztuk Pięknych, „Nowy Dziennik” (1929), nr 167, s. 4. 
Okoliczności jego powstania nie były sprzyjające. Jesienią 1931 r. przez Kraków przetaczała się fala zamieszek antyżydowskich, która dotarła również na krakowską Akademię Sztuk Pięknych. Z tymi zajściami było związane jedno z pierwszych wystąpień członków Zrzeszenia, 21 listopada, kilka dni po zajściach na Akademii. Artyści, oburzeni wydarzeniami i nieudolnością władz uczelni niepotrafiących - ich zdaniem - zareagować w odpowiedni sposób, wystosowali na łamach prasy protest, potępiając „chuligańskie wybryki”. Zaapelowali jednocześnie o tonowanie nastrojów, zwłaszcza w tak trudnej, napiętej sytuacji międzynarodowej, zagrażającej bezpieczeństwu kraju, o którego wolność walczyli również oni sami - jak można przeczytać na stronach „Nowego Dziennika”2. A był to przecież dopiero początek tej trudnej, tragicznej dekady, która zakończyła się wybuchem II wojny światowej przynoszącej zagładę całemu temu środowisku.

Tworzyły go również kobiety. Aby lepiej uzmysłowić sobie ich specyficzną sytuację, warto cofnąć się dekadę wcześniej i przypomnieć bardzo ważną datę: 14 grudnia 1918 r. Tego dnia na wniosek prof. Wojciecha Weissa, rektora Akademii Sztuk Pięknych, na posiedzeniu Grona Profesorów uczelni podjęto jednogłośnie decyzję umożliwiającą kobietom po wielu wcześniejszych staraniach $\mathrm{z}$ ich strony - podejmowanie nauki w murach uczelni razem z mężczyznami, którzy taką możliwością cieszyli się w Krakowie już od ponad stu lat ${ }^{3}$.

Usunięto w ten sposób najpoważniejszą barierę, która stała na drodze kariery artystycznej kobiet, choć z pewnością nie była to bariera jedyna. Decyzja podjęta w pierwszych tygodniach po odzyskaniu niepodległości szybko zaczęła przynosić efekty. Wśród kobiet, które związały się z krakowskim Zrzeszeniem Żydowskich Artystów, absolwentki krakowskiej Akademii Sztuk Pięknych stanowiły największą i najaktywniejszą grupę. Studia były dla nich nie tylko szansą rozwoju czy podążania wybraną ścieżką życiową. W niektórych przypadkach podjęcie edukacji w krakowskiej uczelni sprawiło, że pamięć o nich w ogóle przetrwała. Dzięki danym zachowanym w archiwum szkoły można je zidentyfikować, weryfikować informacje na ich temat, szukać kolejnych śladów, które pozwalają na

2 Protest krakowskich malarzy-Żydów, „Nowy Dziennik” (1931), nr 312, s. 4.

${ }^{3}$ Protokół z posiedzenia Grona Profesorów 14 grudnia 1918 roku, Archiwum Akademii Sztuk Pięknych w Krakowie, sygn. A5, k. 46; Władysław Ślesiński, Studenci, [w:] Materiały do dziejów Akademii Sztuk Pięknych w Krakowie 1895-1939, oprac. Józef E. Dutkiewicz, Jadwiga Jeleniewska-Ślesińska, Władysław Ślesiński, Wrocław 1969, s. 207-209; Iwona Demko, Zofia Baltarowicz-Dzielińska, pierwsza studentka Akademii Sztuk Pięknych w Krakowie, Kraków 2018, s. 89-95. 
bardziej szczegółowe opowiedzenie historii tej części sceny artystycznej międzywojennego Krakowa.

Żydówki skorzystały z szansy kształcenia się na Akademii już w pierwszym roku akademickim, w którym oficjalnie było to możliwe 1919/204. Co najmniej dwie z nich, Maria Fromowicz-Nassau i Bala Leser, kontynuowały po zakończeniu studiów karierę artystyczną, która zwłaszcza w przypadku Bali Leser (posługującej się po wojnie nazwiskiem Zofia Woźna) rozwijała się z dużymi sukcesami ${ }^{5}$. Artystka nie włączyła się w przedsięwzięcia żydowskiego środowiska artystycznego w Krakowie, zrobiła to natomiast Maria Fromowicz-Nassau, która jako jedyna kobieta wzięła udział w I Wystawie Malarzy Żydowskich w Krakowie zorganizowanej przez członków Towarzystwa Krzewienia Sztuk Pięknych w lutym 1930 r. ${ }^{6} \mathrm{~W}$ późniejszych przedsięwzięciach środowiska podejmowanych przez członków Zrzeszenia Żydowskich Artystów nie partycypowała. Wiadomo, że po II wojnie światowej mieszkała i tworzyła we Włoszech ${ }^{7}$.

\section{Członkinie krakowskiego Zrzeszenia Żydowskich Artystów}

Organizacja twórców żydowskich w Krakowie przetrwała do 1939 r. W ciągu ośmiu lat związało się z nią blisko siedemdziesięcioro artystów, w tym jedenaście kobiet $^{8}$. Jako pierwsza akces do Zrzeszenia zgłosiła Henryka Kernerówna (ur. 1892), utalentowana rzeźbiarka z Tarnowa, wykształcona w wiedeńskiej Kunstgewerbeschule (Szkole Rzemiosł

${ }^{4}$ Bala Leser, Maria Fromowicz i Helena Lor rozpoczęły edukację pod kierunkiem Wojciecha Weissa, Romana Szerszewska podjęła naukę w klasie Konstantego Laszczki. Archiwum Akademii Sztuk Pięknych w Krakowie, sygn. A122, KS12 (1919/1920), k. 8.

${ }_{5}^{5}$ Maria Pajek, Katalog rzeźb, obiektów przestrzennych i medali z kolekcji Centrum Rzeźby Polskiej w Orońsku, Orońsko 2013, s. 249-251.

6 Wystawa malarzy żydowskich, ,Sztuki Piękne” 6 (1930), nr 3, s. 110.

7 Agnieszka Janczyk, „Polacca di nascita ed Italiana di adozione” - malarka Maria Fromowicz (1897 - po 1969). Próba uporzadkowania biografii, [w:] Wędrowanie sztuki, red. Artur Badach, Katarzyna Chrudzimska-Uhera, Warszawa 2018, s. 158-169; taż, Fromowiczowie portret rodziny, „Krzysztofory” 35 (2017), s. 475-494.

${ }^{8}$ Zob. Natasza Styrna, Zrzeszenie Żydowskich Artystów Malarzy i Rzeźbiarzy w Krakowie 1931-1939, Warszawa 2009. W książce omówiono zarówno działalność, jak i twórczość artystek, dołączono do niej również ich biogramy. Niniejszy artykuł jest prezentacją nowo uzyskanych informacji na temat członkiń Zrzeszenia oraz uzupełnieniem wątków, które z uwagi na obszerność materiału zawartego w książce nie mogły być w niej rozwinięte. Zob. również: taż, Helena Grabschrift-Taffet, krakowska artystka urodzona w Tuchowie, „Folia Historica Cracoviensia” 27 (2021), z. 1, s. 7-26 (artykuł dotyczący jednej z najmłodszych członkiń Zrzeszenia, która przyłączyła się do organizacji niedługo przed wybuchem II wojny światowej). 


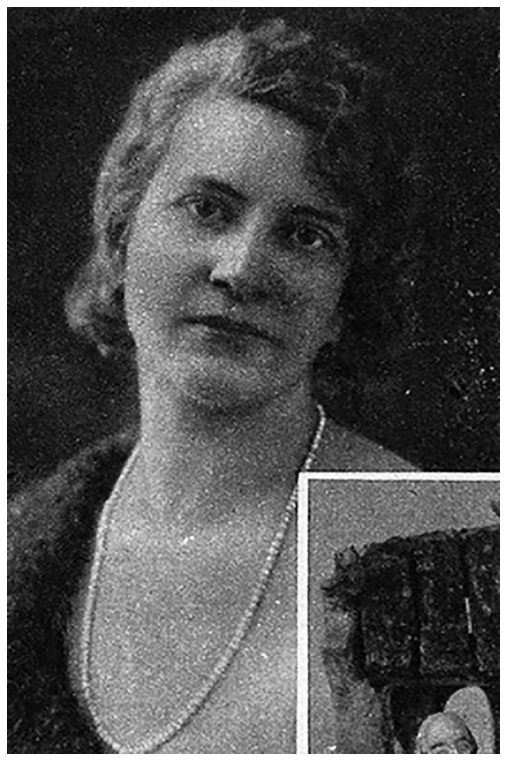

Il. 1. Henryka Kerner, „Światowid” (1934), nr 52, s. 16.

Artystycznych), zob. il. 1. Nieco starsza od wspomnianych wyżej Leser i Fromowicz-Nassau, zmuszona jak wiele kobiet jej pokolenia szukać możliwości studiowania za granicą, po zakończeniu edukacji rozwijała z powodzeniem karierę artystyczną. W ramach Zrzeszenia była aktywna przede wszystkim w początkowym okresie istnienia organizacji. Później zaniechała udziału we wspólnych inicjatywach, lecz cały czas była związana z tym środowiskiem, o czym świadczy zdjęcie z kolekcji Żydowskiego Instytutu Historycznego w Warszawie zrobione w 1938 r. na wystawie Zrzeszenia, gdzie widoczna jest pośród innych członków ugrupowania.

Rzeźbiarka była prawdopodobnie najstarszą artystką związaną ze Zrzeszeniem - gdy się do niego przyłączyła, dobiegała czterdziestki ${ }^{9}$. Jednocześnie była najbardziej wyrazistą osobowością artystyczną wśród twórczyń powiązanych $\mathrm{z}$ tym środowiskiem. Brała udział w wielu wystawach w kraju i za granicą, ceniono ją nie tylko w żydowskich kręgach artystycznych. Jej rozpoznawalności na scenie artystycznej mogły sprzyjać dwie okoliczności dojrzały wiek w okresie współtworzenia organizacji, dający jej dostatecznie dużo czasu, żeby zaistnieć w kręgach artystycznych, oraz pozostawanie przez cały ten okres osobą stanu wolnego, dzięki czemu prawdopodobnie mogła się poświęcać pracy twórczej bez większych przeszkód.

${ }^{9}$ Nie jest znana data urodzenia R. Matzner-Abelesowej, która również uczestniczyła w wystawach Zrzeszenia. 

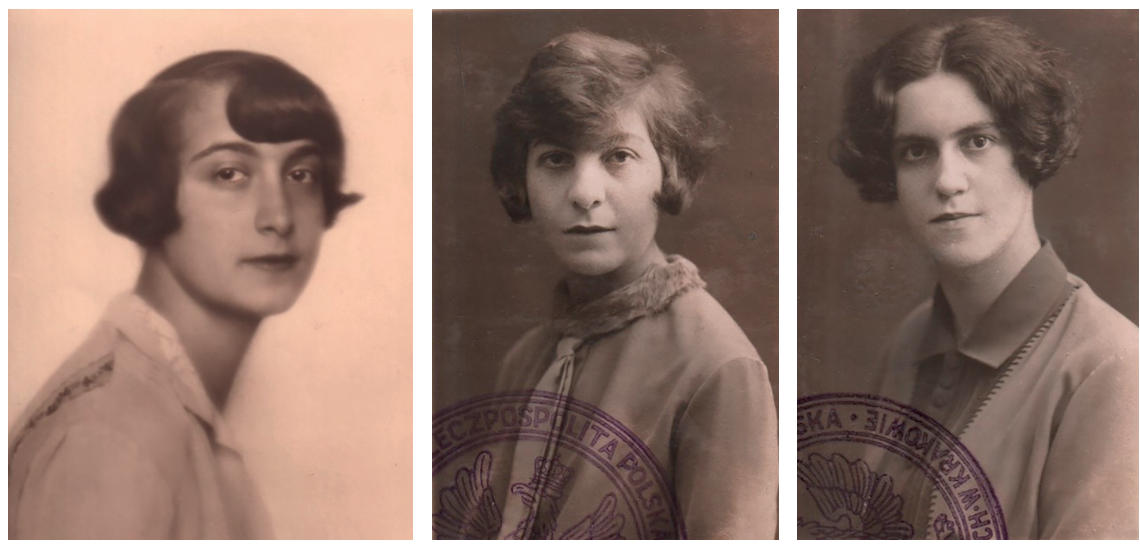

Il. 2. Od lewej: Gizela Nebenzahl-Wistreich, Anna Landau-Eiger, Anna Weingrün-Lieblich, lata trzydzieste, fotografie ze zbiorów Archiwum Akademii Sztuk Pięknych w Krakowie, sygn. A79, T20B.

Kolejne artystki przyłączyły się do Zrzeszenia, gdy działalność organizacji była już dobrze ugruntowana. Wiosną 1933 r. wystawą w Żydowskim Domu Akademickim debiutowała Anna Weingrün (ur. 1904), zob. il. 2. Pod koniec tego samego roku z organizacją związała się nieco bardziej doświadczona na scenie artystycznej Jadwiga Sperling (ur. 1906). Kilka miesięcy później, w styczniu 1934 r., do Zrzeszenia przyłączyła się Gizela Nebenzahl-Wistreich (ur. 1906), a po wakacjach, jesienią 1934 r., Anna Landau (ur. 1904), zob. il. 2.

Biografie czterech wymienionych artystek sporo łączyło. Pochodziły z Krakowa lub jego bliskich okolic, były niemal równolatkami. Edukację rozpoczęły od Wolnej Szkoły Malarstwa i Rysunku im. Ludwiki Mehofferowej w Krakowie, później kontynuowały ją w Akademii Sztuk Pięknych ${ }^{10}$. Artystką z tego grona, która najczęściej wystawiała pod auspicjami Zrzeszenia Żydowskich Artystów, była Anna Weingrün, pozostałe - podobnie jak Kernerówna - udzielały się w ramach organizacji sporadycznie. Zastanawia to zwłaszcza w przypadku Jadwigi Sperling, która była dość aktywna na scenie artystycznej, należała m.in. do Zrzeszenia „Zwornik”, znaczącego ugrupowania artystycznego w Krakowie tych lat. Nie wydaje się, żeby była lekceważona przez kolegów ze Zrzeszenia Żydowskich Artystów. W 1934 r., gdy przygotowywano pierwszy numer wydawanego przez to

${ }^{10}$ Anna Weingrün kształciła się również na Wyższych Kursach dla Kobiet im. Adriana Baranieckiego oraz w Paryżu, a Gizela Nebenzahl w Wiener Frauenakademie. Archiwum Akademii Sztuk Pięknych w Krakowie, sygn. A79, T20B, k. 21, 65. 
środowisko czasopisma „Sztuka i Życie Współczesne”, zaproszono ją do udziału w tym przedsięwzięciu, aby wypowiedziała się obok pięciorga innych członków organizacji oraz autorów takich jak Feliks Kopera czy Leon Chwistek. Jej grafikę wybrano również na okładkę czasopisma ${ }^{11}$.

O pozostałych artystkach należących do Zrzeszenia wiadomo znacznie mniej. W 1935 r. z organizacją związała się R. Matzner-Abelesowa, w 1937 r. zaś Ernestyna Zollman (ur. 1900) - obie trzykrotnie wzięły udział w wystawach Zrzeszenia ${ }^{12}$. Z nielicznych zachowanych dokumentów wynika, że przynajmniej Zollmanówna dość poważnie traktowała swoją aktywność twórczą, konsekwentnie określając się w wypełnianych kwestionariuszach jako artystka-malarka ${ }^{13}$. W zbliżonym czasie, w 1936 r., pierwszy i zarazem jedyny raz w wystawie Zrzeszenia wzięła udział Antonina Richter (ur. 1913), lwowianka spokrewniona za znaną aktorką Kazimierą Rychterówną ${ }^{14}$. Bardziej angażowała się w działalność środowiska lwowskiego, współtworzyła krąg artystów i intelektualistów skupionych wokół znanej fotograficzki Wandy Diamand, utrzymywała również kontakty ze środowiskiem paryskim ${ }^{15}$.

W kolejnych latach, u schyłku dekady, akces do Zrzeszenia zgłosiły jeszcze trzy artystki. Najmocniej swą obecność wśród członków organizacji zaznaczyła Helena Grabschrift (ur. 1909). Współorganizowała ostatnie przed wojną wystawy Zrzeszenia, w 1939 r. odbyła się jej wystawa indywidualna. O jej równolatce, Fryderyce Sternberg, wciąż wiadomo bardzo niewiele. Podobnie jak Grabschriftówna kształciła się na Akademii Sztuk Pięknych w Krakowie, wyszła za mąż za jej absolwenta Abbę Fenichela, wzięła udział w ostatniej wystawie członków Zrzeszenia zorganizowanej przez Grabschriftównę, otwartej pod koniec maja 1939 r. ${ }^{16}$ Prawdopodobnie

${ }^{11}$ Reprodukcji nie podpisano, jednak analiza stylu i tematyki wskazywałaby, że jest to praca Jadwigi Sperling. Jej kompozycja i sposób opracowania przypominają zwłaszcza drzeworyt artystki ze zbiorów Biblioteki Akademii Sztuk Pięknych, Artysta w pracowni, 1931.

${ }^{12}$ Niestety w żadnej notatce na łamach „Nowego Dziennika” nie rozwinięto inicjału imienia R. Matzner-Abelesowej, co obecnie bardzo utrudnia poszukiwanie informacji na jej temat. Ernestyna Zollman urodziła się w Osielcu, a nie w Mielcu, jak bywa podawane. Archiwum Narodowe w Krakowie, sygn. StGKr 1047.

13 Tamże.

${ }^{14}$ Zob. Anna Kaszuba-Dębska, Bruno. Epoka genialna, Kraków 2020, s. 30-31.

${ }^{15}$ Była jedną z osób, które w 1938 r. pomagały Brunonowi Schulzowi zorganizować wyjazd do Francji. Tamże. Zob. też: Renata Piątkowska, Studenci wyznania mojżeszowego w warszawskiej Akademii Sztuk Pięknych (1923-1939). Studia - debiuty - kariery, „Biuletyn Historii Sztuki” (2015), nr 4, s. 679.

${ }^{16}$ Wcześniej uczyła się w Państwowej Szkole Sztuk Zdobniczych i Przemysłu Artystycznego w Krakowie. Archiwum Akademii Sztuk Pięknych w Krakowie, sygn. A78, T21B. 
ostatnią osobą, która ją pamięta, jest Krystyna Treibicz, krakowianka zamieszkała w Izraelu. Dzięki niej wiadomo, że po studiach artystka została zatrudniona w Prywatnym Żydowskim Gimnazjum Żeńskim Towarzystwa Oświatowego „Nasza Szkoła” otworzonym w 1937 r. w Krakowie przy ul. Starowiślnej ${ }^{17}$. Była ulubioną nauczycielką Krystyny Treibicz ${ }^{18}$.

Ostatnia artystka, którą należy tu wymienić, Hanka Lewkowiczówna, była najmłodszą osobą w gronie twórczyń powiązanych z organizacją ${ }^{19}$. Urodziła się w 1918 r., była córką Leona Lewkowicza, jednego z artystów najbardziej zaangażowanych w działalność Zrzeszenia. Przyłączyła się do organizacji jesienią 1938 r., mając zaledwie dwadzieścia lat. Zajmowała się rzeźbą, była również tancerką.

\section{Wybrane przykłady twórczości artystek}

Jak wynika z przytoczonych danych, Zrzeszenie tworzyły zarówno dojrzałe artystki, jak i osoby bardzo młode. Jego członkinie zajmowały się różnymi dyscyplinami artystycznymi, preferowały odmienne techniki artystyczne. Część z nich z powodzeniem funkcjonowała na scenie artystycznej, inne pozostają dzisiaj niemal zupełnie nieznane. Niestety z ich dorobku przetrwało niewiele. W czasie wojny artystki, zmuszone uciekać, zamykane w gettach, obozach, nie były w stanie troszczyć się o swoje prace. Te, które przeżyły, czasem po wojnie nie miały już do czego wracać. Tylko pojedyncze prace członkiń Zrzeszenia trafiły do kolekcji muzealnych. Jeśli przed wojną udało im się coś sprzedać, ich obrazy mogą nadal wisieć w mieszkaniach osób niemających świadomości, kto je namalował ani z jakim środowiskiem był związany. Niestety nie można wykluczyć, że część trafiła na śmietnik. Zdarza się to nawet w przypadku najbardziej znanych członków i członkiń Zrzeszenia, lecz jest jeszcze bardziej prawdopodobne w przypadku młodszych artystów, którzy nie zdążyli sobie przed wojną

${ }^{17}$ Zob. Zygmunt Ruta, Prywatne szkoty średnie ogólnoksztatcace w Krakowie i województwie krakowskim w latach 1932-1939, Kraków 1990, s. 23.

${ }^{18}$ Była „wspaniałą nauczycielką”, dobrą i ciepłą osobą - takimi słowami w rozmowie z autorką Krystyna Treibicz wspominała Frydę Sternberg po osiemdziesięciu latach. Do tej samej szkoły uczęszczała Alina Dankowicz. Zapamiętała, że obie z Krystyną nie chciały się uczyć rysunku i malarstwa, wolały lekcje szycia. Obu przedmiotów uczyła Fryderyka Sternberg.

${ }^{19}$ Zdrobnieniem „Hanka” posługiwano się na łamach „Nowego Dziennika” w przypadku Anny Landau i właśnie Hanki Lewkowicz. Odnalazłam dokumenty potwierdzające oficjalną wersję imienia Anny Landau i nią się posługuję. W przypadku Hanki Lewkowicz stosuję wersję utrwaloną na stronach „Nowego Dziennika”. 
wyrobić nazwiska. A właśnie do tej generacji należała większość kobiet związanych z organizacją.

Malarstwo członkiń Zrzeszenia szerzej zostało omówione w opublikowanej w 2009 r. książce dotyczącej organizacji ${ }^{20}$. W niniejszym opracowaniu uwagę należałoby poświęcić wątkom, które nie były w niej poruszane. Większego zainteresowania wymagałaby zwłaszcza twórczość rzeźbiarek Henryki Kernerówny i Hanki Lewkowicz. Warto również zwrócić uwagę na prace graficzne malarek, które należały do Zrzeszenia.

Dorobek Henryki Kernerówny jest znany przede wszystkim z reprodukcji w przedwojennej prasie. Trzy obiekty jej autorstwa wykonane w typowej dla niej technice zbliżonej do majoliki zachowały się również w zbiorach Muzeum Narodowego w Krakowie. Pochodzą one z okresu, zanim artystka włączyła się w działalność Zrzeszenia Żydowskich Artystów. Figurkę Damy zakupiono w 1929 r., grupa figuralna Trzy Marie oraz kropielniczka trafiły do Muzeum Narodowego ze zbiorów Muzeum Przemysłowego, do których zostały nabyte w 1930 r. na wystawie Towarzystwa Przyjaciół Sztuk Pięknych.

Cztery lata wcześniej w tej samej instytucji odbył się debiutancki pokaz prac rzeźbiarki po jej powrocie z Wiednia. Ceramiką fascynowała się ponoć od dzieciństwa ${ }^{21}$. W Wiedniu dostała się pod skrzydła wybitnego rzeźbiarza Antona Hanaka, dyrektora Kunstgewerbeschule, który nie szczędził jej pochwał, jak można przeczytać w recenzji wspomnianej wystawy ${ }^{22}$. Cztery lata po podjęciu nauki wzięła udział w wystawie Hagenbundu ${ }^{23}$. Nieco później wystawiała w wiedeńskim Künstlerhaus (Domu Artystów) oraz w Lipsku, zdobywając - jak relacjonował autor powyższej recenzji liczne pochwalne wzmianki w prasie ${ }^{24}$. Poszły za nimi pierwsze zakupy do poważnych instytucji, drezdeńskiego Muzeum Przemysłowego czy Salonu Nebehaya w Wiedniu ${ }^{25}$.

Po powrocie do kraju jej twórczość również szybko zaczęła się cieszyć zainteresowaniem. Pisano o jej talencie, silnej indywidualności, polocie,

${ }^{20}$ Styrna, Zrzeszenie...

${ }^{21}$ Henryk Weber, Na wysepce majolikowej (W atelier Henryki Kernerówny), „Nowy Dziennik" (1931), nr 145, s. 9.

${ }^{22}$ A. H., Wystawa plastyk Henryki Kernerówny w Tow. Sztuk Pięknych w Krakowie, „Naprzód" (1926), nr 97, s. 6.

${ }^{23}$ Hagenbund, istniejące w latach 1900-1938 stowarzyszenie artystów, jedno z najważniejszych w tym okresie w środowisku wiedeńskim. Zob.: Die Verlorene Moderne: Der Künstlerbund Hagen 1900-1938 (katalog wystawy), Österreichische Galerie Belvedere, Wien 1993.

${ }^{24}$ A. H., Wystawa plastyk..., s. 6.

${ }^{25}$ Tamże. 
ciekawej technice pracy czy przemyślanym doborze materiału, po który sięgała ${ }^{26}$. Na wyróżnienie zasługiwałaby zwłaszcza recenzja Tadeusza Szafrana, doskonale zorientowanego w poruszanej problematyce kierownika wydziału ceramiki w krakowskiej Szkole Sztuk Zdobniczych i Przemysłu Artystycznego. Szafran chwalił artystkę za prostotę, różnorodność stosowanych rozwiązań oraz umiejętność wystrzegania się wszelkich powierzchownych czy banalnych chwytów mogących skusić kogoś mniej obeznanego z tajnikami techniki, którą się posługiwała ${ }^{27}$. W recenzjach i komentarzach szczególnie często wspominano o ogromnych trudnościach, z jakimi musiała się mierzyć, aby realizować swoje pasje. Przede wszystkim brakowało jej odpowiedniej pracowni, co zmuszało ją do wypalania prac „kątem, w cudzym piecu kaflarskim” - nierzadko powodowało to rozmaite uszczerbki w wykonywanych obiektach czy wręcz unicestwiało jej wysiłki ${ }^{28}$.

W jej dorobku szczególną uwagę zwraca tematyka religijna - Święta Rodzina, wspomniane Trzy Marie, Hołd Trzech Króli, liczne Madonny. Można odnieść wrażenie, że funkcjonowanie w otoczeniu chrześcijańskiej większości, styczność na każdym kroku z tego rodzaju wizerunkami oddziaływały niezwykle mocno na jej wyobraźnię artystyczną. Nie można oczywiście wykluczyć, że podejmując tego rodzaju wątki, liczyła na łatwiejsze znalezienie nabywców na swoje prace, chociaż nie wydaje się, że był to główny czy istotny powód sięgania po takie motywy. Traktowała te figurki z takim samym autentyzmem i szczerością jak wszystkie inne, nie starając się bynajmniej w żaden sposób schlebiać gustom odbiorców.

Równie często podejmowała temat aktu kobiecego. Podobnie jak w przypadku tematyki religijnej - najchętniej wybierała glinę. Przedstawiała postaci zazwyczaj w pozycji stojącej. Jej rzeźby miały pełne kobiece kształty, co nie odbierało im wcale smukłości czy lekkości. Ich długie, wijące się w splotach włosy opadały na krągłe ramiona. Formy były uproszczone, a połyskująca polewa dodatkowo zacierała szczegóły, prowadząc do pewnego odrealnienia sylwetek. Wzrok kobiet przedstawionych w akcie był skierowany zazwyczaj na wprost lub delikatnie ku górze w przeciwieństwie do postaci świętych i madonn z troską spoglądających przeważnie ku dołowi. Innym znakiem rozpoznawczym aktów autorstwa

${ }^{26}$ H. W. [Henryk Weber], Wystawa ceramik Henryki Kernerównej w Tarnowie, „Nowy Dziennik” (1931), nr 166, s. 9; Henryka Kernerówna, „Światowid” (1934), nr 52, s. 16; H. Gościnna, Z Krakowskiego Pałacu Sztuki, „Przegląd Artystyczny” (1936), nr 1, s. 10.

${ }_{27}$ Tadeusz Szafran, Prace ceramiczne Henryki Kernerówny, „Rzeczy Piękne” (1930), s. 55.

28 Tamże. 
Kernerówny była draperia osuwająca się z kobiecych bioder, tyle samo przysłaniająca, ile odsłaniająca nagość modelki. Oprócz aktów artystka tworzyła również figurki dam w mniej lub bardziej strojnych sukniach oraz główki kobiet z różnych stron świata, np. główka Chinki lub główka czarnoskórej kobiety ${ }^{29}$.

Jedno z najciekawszych dzieł w swoim dorobku, rzeźbę Salome (il. 3), Kernerówna zaprezentowała w 1930 r. na wystawie w Salonie Garlińskiego w Warszawie ${ }^{30}$. W ocenie wspominającej tę pracę Bolesławy Kołodziejowej rzeźbiarkę interesowały wizerunki „kobiet zwycięskich, lecz przegranych, przenikniętych chłodem śmierci" ${ }^{31}$. Gdy jednak przyglądamy się figurze, to nie chłód śmierci nasuwa się nam na myśl, lecz coś zupełnie innego. Bohaterkę przedstawiono w akcie, na jej twarzy maluje się rozkosz, zmysłowe uniesienie. Głowa mężczyzny, sprawiającego wrażenie raczej uśpionego niż martwego, spoczęła na jej piersi. Nietrudno o wrażenie, iż biblijny temat posłużył tu jedynie jako pretekst, aby ukazać pogrążoną w ekstazie kobietę.

Artystka w swej interpretacji Salome wyeksponowała przede wszystkim jej postać. Jej ciało jest szczupłe, lecz masywnie zbudowane, biodra są wąskie, a piersi nieduże. Nie ma w tym próby przyciągnięcia łakomego wzroku widza, by ślizgał się po krągłościach kobiecego ciała. Uwagę przyciąga raczej fizjonomia bohaterki zanurzonej pod zamkniętymi powiekami w świecie zmysłowej rozkoszy i obojętnej na wszystko wokół. Opadająca ku tyłowi głowa, odrzucone za siebie ramię wzmagają poczucie, że jest to chwila odprężenia, półsennego letargu. Z sylwetką o uproszczonych obłych kształtach kontrastują gęste, zwichrzone włosy kobiety. Niesforne pukle układają się w różnych kierunkach, sprawiając wrażenie żywiołu nie do ogarnięcia. Zupełnie inaczej zostały potraktowane włosy mężczyzny - krótkie i przylegające do głowy, układające się w regularne, lekko pofalowane pasma okalające twarz, uporządkowane, poddane pewnemu schematowi kontrastującemu z bujną i nieokiełznaną fryzurą kobiety.

${ }^{29}$ Instytut Sztuki Polskiej Akademii Nauk, zbiory specjalne, nr inw. 1776/II.

${ }^{30}$ Fotografia rzeźby opatrzona takim samym tytułem i datą zachowała się w Archiwum Ilustracji Koncernu Ilustrowanego Kuriera Codziennego, sygn. 1-K-3516. Jednocześnie, w tym samym roku, fotografię rzeźby - podpisaną jako Judyta - opublikowano na łamach „Rzeczy Pięknych”. Do artykułu dołączono więcej reprodukcji prac artystki, m.in. zdjęcie figurki, bez tytułu, przedstawiającej nagą kobietę trzymającą w ręku głowę brodatego mężczyzny. Melancholijna, zadumana postać różni się mocno od pogrążonej w zmysłowej ekstazie Salome, ponadto zdaje się dzierżyć w ręku miecz stanowiący atrybut Judyty. Prawdopodobnie doszło zatem do pomyłki. Szafran, Prace ceramiczne Henryki Kernerówny..., s. 55-56.

${ }^{31}$ Bolesława Kołodziejowa, Ceramika krakowska I poł. XX wieku, „Rocznik Muzeum Mazowieckiego w Płocku” 14 (1991), s. 143. 


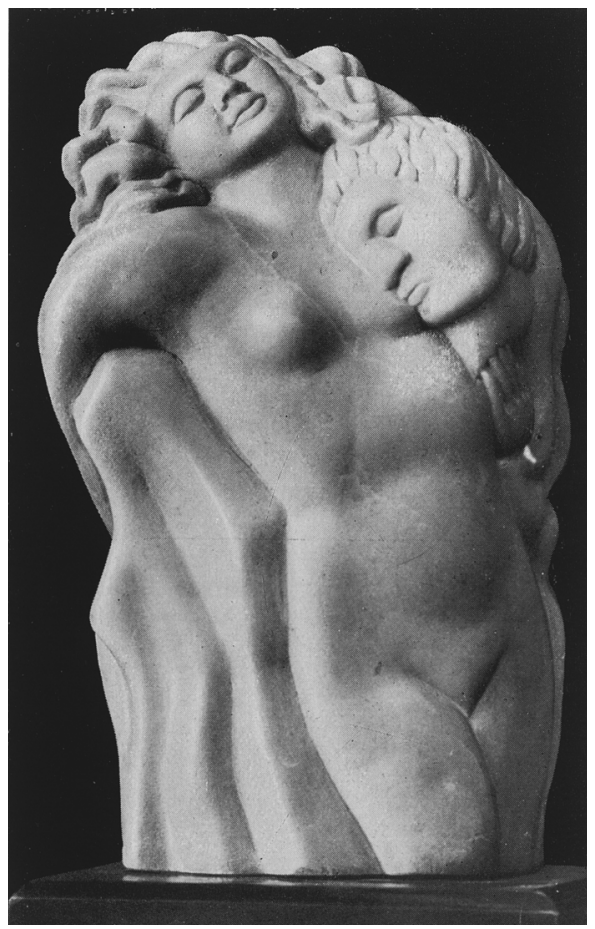

Il. 3. „Rzeźba w kamieniu dłuta artystki rzeźbiarki Henryki Kernerówny Salome”, 1930, fotografia, Archiwum Ilustracji Koncernu Ilustrowanego Kuriera Codziennego, sygn. 1-K-3516.

W bohaterce nie ma okrucieństwa ani bezwzględności kojarzonych z postacią Salome, nie jest to również bezmyślna dziewczyna nieświadoma swych czynów, lecz raczej instynktownie, bez skrępowania skoncentrowana na własnych odczuciach kobieta. Sięgając po niezwykle popularny temat, szczególnie na przełomie XIX i XX w., artystce udało się zdjąć z niego nieco odium demoniczności, perwersyjnej lubieżności, nie zatracając jednocześnie tkwiącego w nim zmysłowego ładunku².

W Polsce zainteresowanie wątkiem Salome przetrwało jeszcze dłużej. Podejmowali go m.in. Jacek Malczewski (1908, 1909, 1911,1912), Tymon Niesiołowski (1909), Kazimierz Sichulski (1912), Feliks Michał Wygrzywalski (1925) czy Edward Okuń (1928, 1939). W dziełach wymienionych

${ }^{32}$ Więcej na temat popularności tego wątku w literaturze, muzyce i sztuce wspomnianego okresu zob. Dariusz Trześniowski, „A trwanie twoje jest jak śmierć, na zawsze - coraz straszniejsze i krwawsze”. Modernistyczny wizerunek Salome, „Pamiętnik Literacki” (2001), z. 1 , s. $7-31$. 
artystów nie znajdziemy jednak treści, na które tak silny nacisk w swojej pracy położyła artystka. Salome, którą przedstawiali, przeważnie emanowała chłodem, była zdystansowana. Na jej ustach mógł gościć cyniczny uśmiech, mogła być niepokojąca, wyrachowana, ale nigdy nie była kobietą erotycznie spełnioną jak w ujęciu rzeźbiarki.

Temat interesował również rzeźbiarzy działających w tym okresie. W zbliżonym czasie, co Kernerówna podjęli go m.in. Wojciech Durek (1929) czy Konstanty Laszczka (ok. 1930). Pełna gracji, naga, tańcząca Salome Laszczki o ciele przyozdobionym biżuterią, kojarząca się z dziełami XIX-wiecznego orientalizmu, pod każdym względem odbiega od pracy artystki ${ }^{33}$. Nieco bliższa rzeźbie Kernerówny jest Salome Wojciecha Durka, zwłaszcza poza, w jakiej rzeźbiarz przedstawił bohaterkę ${ }^{34}$. Jej ciało ujęto do połowy ud, ręce Salome podobnie jak w pracy Kernerówny są odrzucone do tyłu. Jednak pewna sztywność w potraktowaniu sylwetki przez rzeźbiarza, twardy modelunek, silna geometryzacja w partii włosów, tworzą całość o zupełnie innym charakterze niż rzeźba Kernerówny. Chłód, skupienie rysujące się na twarzy bohaterki Durka bez emocji przyglądającej się ściętej głowie Jana pogłębiają tę różnicę.

Salome Kernerówny pozostaje czymś wyjątkowym również na tle jej własnego dorobku. Androgyniczne ciało sportsmenki połączone z twarzą hinduskiej bogini, o grubych, ciężkich powiekach i wyeksponowanych ustach, odstaje wyraźnie od eterycznych, delikatnych figurynek połyskujących barwną polewą, które zazwyczaj tworzyła.

Kernerówna wypalała swoje prace ceramiczne w piecu kaflarskim w Tarnowie, prawdopodobnie w Bracha, jak podaje Maria Starzewska ${ }^{35}$. Z kolei zdaniem Kołodziejowej miała w Tarnowie wspólną pracownię z Henrykiem Hochmanem. Starszy o trzynaście lat rzeźbiarz, uczeń Konstantego Laszczki oraz Auguste'a Rodina, uchodził za jej nauczyciela. Pracowali czasem wspólnie i niewątpliwie łączyła ich zażyłość, lecz Bolesława Kołodziejowa słusznie podkreślała niezależność artystki ${ }^{36}$. Już po wybuchu wojny w krakowskiej pracowni Hochmana bywał Henryk Schönker, syn

${ }^{33}$ Zob.: Zofia Weiss, Katarzyna Łomnicka, Konstanty Laszczka, Kraków 2016, s. 128.

${ }^{34}$ Rzeźbiarz był związany z różnymi środowiskami, przez jakiś czas mieszkał też w Krakowie. Naukę rozpoczął w krakowskiej Szkole Przemysłu Artystycznego, później przebywał za granicą. W 1920 r. na wystawie Towarzystwa Przyjaciół Sztuk Pięknych w Krakowie miał miejsce jego debiut artystyczny po powrocie do kraju.

${ }^{35}$ Maria Starzewska, Polska ceramika artystyczna pierwszej połowy XX wieku, Wrocław 1952, s. 25. Autorka miała na myśli zapewne cegielnię Kantoria Władysława Bracha w Tarnowie.

${ }^{36}$ Kołodziejowa, Ceramika krakowska ..., s. 144. 
Leona Schönkera, wieloletniego prezesa Zrzeszenia Żydowskich Artystów w Krakowie. W napisanych u schyłku życia wspomnieniach określił Kernerównę jako towarzyszkę życia rzeźbiarza. Przed wojną oboje mieszkali w tym miejscu, ale wtedy, gdy bywał tam Henryk Schönker, Kernerówny już nie było, wyjechała z kraju, zostawiając pod opieką Hochmana szesnaście kotów syjamskich, „o które dbała, jakby to były jej dzieci” ${ }^{37}$. Coś, co mogłoby się wydawać barwnym, anegdotycznym wspomnieniem, ma tak naprawdę wymiar tragiczny. Nastoletni autor wspomnień, bawiąc się z głodnymi kotami, mógł choć na chwilę zapomnieć o rozgrywającym się wokół koszmarze. Nie trwało to jednak długo, ponieważ zarówno Schönkerowie, jak i Hochman musieli uciekać, rzeźbiarza zamordowano niedługo później w Baczkowie koło Bochni.

W dziecięcych wspomnieniach Schönker utrwalił wątek wydawałoby się poboczny - przywiązanie artystki do zwierząt. Nie uszedł on uwadze badaczy. Już Magdalena Samozwaniec wzmiankowała, że wiele artystek czy literatek w jej czasach „pasjonowało się zwierzętami, na niekorzyść dzieci, których przeważnie nie miewały"38. Do nazwisk wymienionych przez Samozwaniec Joanna Sosnowska w książce poświęconej twórczości polskich artystek na przełomie wieków i w latach międzywojennych dodała kolejne, umieszczając Kernerównę na pierwszym miejscu ${ }^{39}$. W tym przypadku słabość ta charakteryzowała oboje artystów, nie tylko Kernerównę. Po jej wyjeździe wszystkie trudy związane z opieką nad zwierzętami przejął rzeźbiarz. Jak wspominał Schönker, ich obecność była dla niego prawdziwą ostoją, pozwalała mu utrzymać względną równowagę psychiczną w czasie, gdy był już bliski załamania. Z przejmującego zapisu przeżyć wojennych Schönkera wynika, że nie tylko artystka, ale również Hochman kochał je jak własne dzieci.

Fotografie prac Kernerówny z lat międzywojennych pozwoliły na rozwinięcie wątku aktu kobiecego w twórczości artystki. Tematyka ta była obecna również w dorobku Anny Weingrün. W Bibliotece Akademii Sztuk Pięknych w Krakowie zachowały się dwa akty jej autorstwa. Prace wykonane w technice akwaforty przedstawiają drobną, jasnowłosą, pełną uroku młodą kobietę pośród draperii, prawdopodobnie modelkę zatrudnioną na krakowskiej Akademii. Interesujący jest zwłaszcza wizerunek

${ }^{37}$ Henryk Schönker, Dotknięcie anioła, Warszawa 2005, s. 72.

${ }^{38}$ Magdalena Samozwaniec, Maria i Magdalena, Kraków 1956, s. 304.

39 Joanna Sosnowska, Poza kanonem. Sztuka polskich artystek 1880-1939, Warszawa 2003, s. 208. 


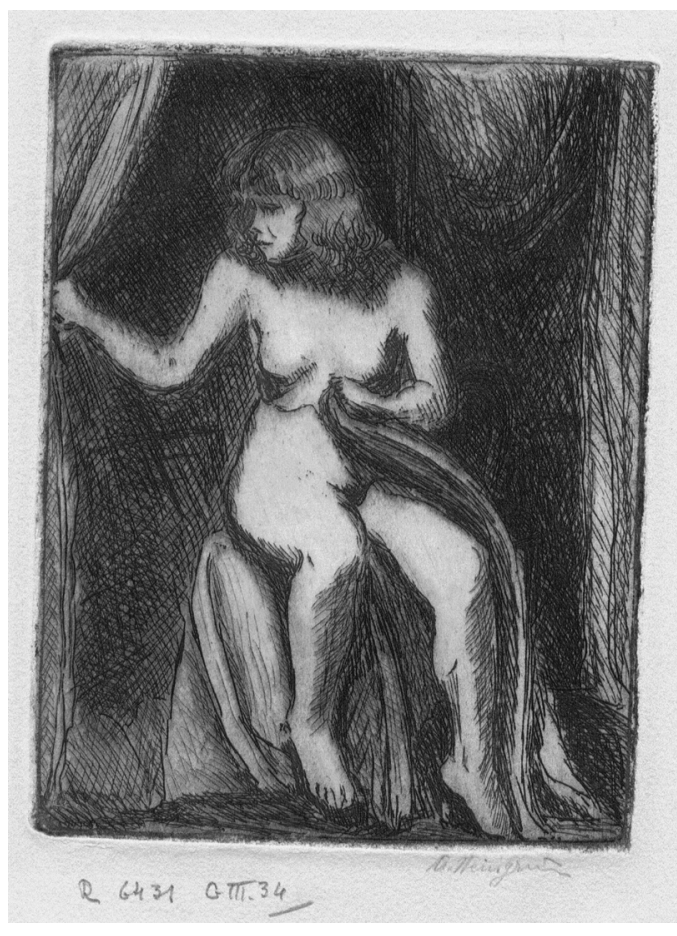

Il. 4. Anna Weingrün-Lieblich, Studium aktu kobiety siedzacej, akwaforta, Biblioteka Akademii Sztuk Pięknych w Krakowie, sygn. 6431.

dziewczyny w siedzącej pozie, uchylającej łagodnym gestem zasłonę (il. 4). Praca zwraca uwage pełnym ciepła skupieniem rytowniczki na kruchości i delikatności dziewczyny. To nie tyle typowe dla szkoły artystycznej studium proporcji ludzkiego ciała, co raczej intymna scena we wnętrzu, gdzie naturalność i zaznaczony rys indywidualny przedstawionej postaci grają pierwszoplanową rolę. Ciepło oraz delikatna nuta humoru są też wyczuwalne w innych pracach artystki, zwłaszcza przedstawieniach sylwetek ludzkich charakteryzowanych z wyczuwalną sympatią, często za pomoca jedynie kilku nieskomplikowanych kresek.

Stan zachowania prac artystek tworzących Zrzeszenie sprawia, że trudno jest formułować sądy uogólniające na temat ich dorobku. Wyciąganie wniosków na podstawie pojedynczych ocalałych dzieł jest obarczone ryzykiem błędu, zwłaszcza że mogą to być obiekty dość przypadkowe, które wcale nie były reprezentatywne dla ich twórczości. Czasem łatwiej zdanie na temat dokonań artystek wyrobić sobie na podstawie recenzji ich wystaw, pisanych przez autorów, którzy znali ich prace w większym wyborze. $Z$ tekstów publikowanych przed wojną wynika, że podejmowały 
bardzo różnorodną tematykę. Tworzyły martwe natury, pejzaże, malowały sceny rodzajowe i portrety. Wśród modeli artystki wybierały, co istotne, przede wszystkim kobiety, nieco rzadziej dzieci. Dotyczyłoby to Anny Weingrün i Jadwigi Sperling, w przypadku zaś Antoniny Richter, uczestniczki wystawy Portret kobiecy w Żydowskim Towarzystwie Krzewienia Sztuk Pięknych w Warszawie w 1939 r., przeradzało się w swoistą specjalizację ${ }^{40}$. Wśród rozwiązań formalnych w twórczości malarek dominowały, jak się wydaje, tendencje bliskie koloryzmowi, czasem ze skłonnością do silniejszego podkreślania ekspresji przedstawiań.

O twórczości kolejnej rzeźbiarki ze Zrzeszenia, Hanki Lewkowiczówny, można się wypowiadać niemal wyłącznie na podstawie recenzji w międzywojennej prasie. Nie wynika z nich jednoznacznie, której ze swoich pasji artystycznych absolwentka Gimnazjum Hebrajskiego w Krakowie poświęcała się bardziej - rzeźbie czy tańcowi? Można natomiast się zorientować, że niezależnie od dziedziny, na której się koncentrowała, jej twórczość cechowała duża wrażliwość społeczna. Warto wyróżnić zwłaszcza jedną z jej kompozycji tanecznych zaprezentowanych wiosną 1939 r. w Sali Saskiej w Krakowie, zatytułowaną Ulicznica, wprost odnoszącą się do losu najuboższych kobiet, który najwyraźniej nie pozostawał obojętny młodej artystce ${ }^{41}$. Lewkowiczówna była pomysłodawczynią układów, które tańczyła, autorką choreografii i nierzadko muzyki. Można się domyślać, że potraktowała ten temat z charakterystyczną dla siebie wrażliwością i głębią, za które była ceniona przez krytyków. O jej wrażliwości społecznej świadczą również słowa Henryka Webera, który przy okazji recenzowania jej dorobku rzeźbiarskiego po raz kolejny zwracał uwagę na zajmujące ją najbardziej kwestie biedy i nędzy. Pisząc o „upiorności” tego rodzaju wątków, krytyk podkreślał zarazem silniejszą, jak się wydaje, niż u pozostałych artystek tworzących Zrzeszenie skłonność rzeźbiarki do sięgania po repertuar środków wyrazu typowy dla ekspresjonizmu ${ }^{42}$.

Jako modele pewnym zainteresowaniem artystki - podobnie jak w przypadku jej ojca Leona Lewkowicza - cieszyły się również dzieci. W zbiorach jej siostry, Ruth Goldberger, zachowała się fotografia rzeźby

${ }^{40}$ Portrety kobiece pędzla Antoniny Richter są znane z reprodukcji na łamach lwowskich „Sygnałów”, zob. L. Strakun, Z wystaw warszawskich, „Sygnały” (1939), nr 64, s. 8. Tenże, Z wystaw, „Sygnały” (1939), nr 67, s. 6. Również po wojnie w Izraelu artystka pozostała wierna tej tematyce.

${ }^{41}$ Ygrek, Wieczór tańców Hanki Lewkowiczówny, „Nowy Dziennik” (1939), nr 120, s. 10.

${ }^{42}$ H. W., Wystawa rzeźb i ceramiki Hanki Lewkowiczówny, „Nowy Dziennik” (1938), nr 340, s. 17. 


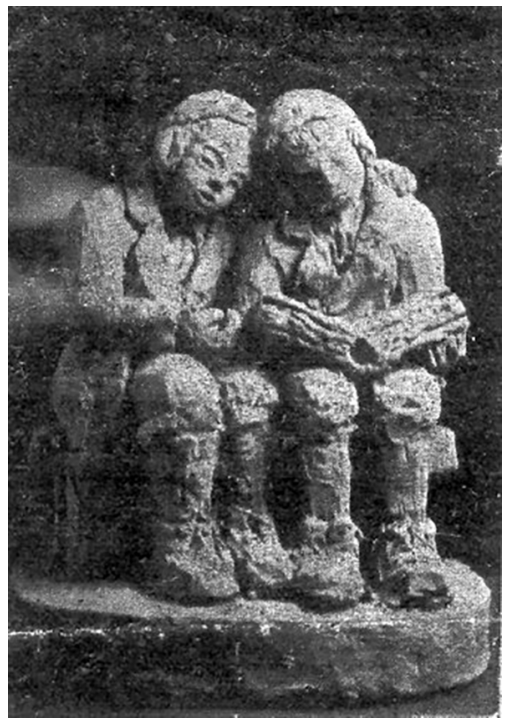

Il. 5. Hanka Lewkowicz, Mali talmudyści, fotografia ze zbiorów Ruth Goldberger.

jej autorstwa Mali talmudyści (il. 5), przedstawiająca dwójkę obejmujących się chłopców pochylonych nad książką. Postaci są proporcjonalne, a ruch i gesty wydają się dobrze uchwycone. Kompozycji nie brakuje wdzięku, podkreślony jest zwłaszcza związek emocjonalny między dziećmi. Inne prace Lewkowiczówny zawierały, jak się wydaje, więcej charakterystycznego dla niej dramatyzmu. W 1939 r. na łamach prasy wspominano o jej pracy, w której prawdopodobnie skumulowały się wszystkie najważniejsze wątki poruszające artystkę - przedstawieniu bezdomnej kobiety, „zastygłej z bólu, tulącej do siebie zziębnięte maleństwa”. Obok można było zobaczyć bezrobotnego, który „z tępym spojrzeniem wsparł się ciężko o łopatę i daremnie czeka na pracę"43.

Choć w sposób nie tak wyrazisty jak u Lewkowiczówny ekspresja dochodziła do głosu również w pracach graficzki Heleny Grabschrift, koncentrującej się na oddawaniu ponurego nastroju opustoszałych podwórek albo surowych, pozbawionych nadmiaru elementów pejzaży. Podobnie jak Lewkowiczównie również nieobca była jej tematyka społeczna. Motyw, do którego wracała szczególnie często, to przedstawienie ubogiej chłopki, zziębniętej, opatulonej w chusty lub zajętej pracą ${ }^{44}$.

${ }^{43}$ Dzieci na wystawie, wycinek prasowy z 1939 r. ze zbiorów Ruth Goldberger.

${ }^{44}$ Więcej na temat artystki zob.: Styrna, Helena Grabschrift-Taffet... 
Odnośnie do twórczości pozostałych członkiń Zrzeszenia niewiele można dodać do tego, co już zostało napisane. Anna Landau była zdolną rysowniczką, Gizela Nebenzahl - jak wynikałoby z recenzji Webera również dysponowała dużym talentem ${ }^{45}$. Obie artystki wyszły za mąż w latach trzydziestych. Landauówna, już jako Anna Eigerowa, w kwestionariuszu wypełnianym w 1938 r. w rubryce zawód wpisała „żona kupca”, pomijając zupełnie swoje doświadczenia artystyczne i kilkuletnią edukację w tym zakresie ${ }^{46}$. Pejzażystka Gizela Nebenzahl wyszła za dermatologa Bernarda Wistreicha i zamieszkała w Katowicach. W 1935 r. urodziła syna. Prawdopodobnie jako jedyna z wymienionych tu kobiet została matką w okresie współtworzenia krakowskiego Zrzeszenia Żydowskich Artystów. Udział w wystawach niedługo przed wojną świadczył, że gdy dziecko podrosło, usiłowała powrócić do dawnej aktywności.

\section{Członkinie Zrzeszenia wśród kolegów z organizacji}

Oprócz najważniejszych faktów dotyczących artystek ze Zrzeszenia warto byłoby również rozważyć kwestię relacji między nimi a pozostałymi członkami organizacji. Tylko młodsi z nich spotykali się w murach krakowskiej Akademii z koleżankami, starsi mogli być przyzwyczajeni do kobiet w szkole raczej w roli modelek niż pełnoprawnych partnerek w zdobywaniu wiedzy i szlifowaniu warsztatu. Jak zatem reagowano w kręgu artystów żydowskich w Krakowie na rosnące ambicje zawodowe kobiet w dziedzinie sztuki i czy poddawano jakiejś refleksji zmieniającą się sytuację w tym zakresie?

Recenzje wystaw organizowanych w Żydowskim Domu Akademickim, ograniczające się zazwyczaj do merytorycznych uwag na temat prezentowanego dorobku, pomagają nabrać wyobrażenia o poziomie artystycznym prac tworzonych przez członkinie Zrzeszenia, jednak w niewielkim stopniu dają pojęcie, jak były one traktowane przez kolegów ani z jakimi odczuciami wiązał się dla nich udział we wspólnych przedsięwzięciach. Recenzje te ukazywały się wyłącznie na stronach wydawanego w Krakowie żydowskiego „Nowego Dziennika”. Autorem większości z nich był Henryk Weber, czasem teksty krytyczne pisali również związani ze Zrzeszeniem malarze ${ }^{47}$.

${ }^{45}$ Henryk Weber, Wystawa „Zrzeszenia”, „Nowy Dziennik” (1934), nr 22, s. 9.

${ }^{46}$ Archiwum Narodowe w Krakowie, sygn. StGKr 848.

47 Jedyną, jaką udało mi się odnaleźć, recenzją wystawy Zrzeszenia Żydowskich Artystów autorstwa kobiety jest tekst Henryki Fromowicz-Stillerowej, starszej siostry Marii 
Na pewno artystki nie stroniły od organizacji, nie wydaje się również, żeby były marginalizowane ${ }^{48}$. Niektóre wykruszały się po jednej wystawie, inne chętnie po kilka razy prezentowały swój dorobek w ramach Zrzeszenia $^{49}$. Brak formalnego wykształcenia w zakresie sztuk pięknych nie stanowił dla władz organizacji przeszkody, aby zaprosić utalentowaną osobę do wspólnej wystawy, o ile tylko dysponowała ona interesującym, wartościowym dorobkiem. Autorzy recenzji traktowali wszystkich uczestników wystaw z należytym szacunkiem, ale nie wahali się używać krytycznych sformułowań, jeśli wymagała tego sytuacja. Dlatego można się spodziewać, że dorobek kobiet był po prostu oceniany rzetelnie, bez taryfy ulgowej. Podobnie jak koledzy mogły się spodziewać zarówno wyrazów uznania, jak i przygan ze strony Henryka Webera, który był najważniejszym krytykiem związanym z organizacją. Bezapelacyjny aplauz budził w nim jedynie dorobek Kernerówny, której nie szczędził wyszukanych pochwał.

Z rzadka wystawy recenzował też Emil Schinagel, lekarz, malarz i przez pewien okres prezes Zrzeszenia. Szczęśliwego zrządzenia losu, jakim była recenzja debiutanckiej wystawy pióra tak wrażliwej i empatycznej osoby, jaką był Schinagel, doczekała się Anna Weingrün. Znaczna część bardzo

Fromowicz-Nassau, dotyczący dorobku Wilhelma Wachtla. Henryka Fromowicz-Stillerowa, Z wystawy w Żydowskim Domu Akademickim. Wystawa Wilhelma Wachtla, „Nowy Dziennik" (1933), nr 107, s. 15.

${ }^{48}$ W 1935 r. do najściślejszego grona osób zaangażowanych w pracę Zrzeszenia, tzw. wydziału, weszły dwie artystki: Anna Landau i R. Matzner-Abelesowa. Tego samego roku Anna Landau dołączyła również do komitetu koordynującego działania podejmowane w ramach „Ośrodka Artystów” założonego z inicjatywy żydowskich plastyków w mieście. W 1938 r. w skład zarządu Zrzeszenia weszły Ernestyna Zollman i Helena Grabschrift. Dzięki tej ostatniej organizacja bardzo sprawnie funkcjonowała aż po ostatnie przedwojenne miesiące. Walne zgromadzenie Zrzeszenia Żydowskich Artystów Malarzy i Rzeźbiarzy w Krakowie, „Nowy Dziennik” (1935), nr 314, s. 9; Z „Ośrodka artystów”, „Nowy Dziennik” (1935), nr 326, s. 11; Archiwum Narodowe w Krakowie, sygn. StGKr 247, k. 341.

${ }^{49}$ Trudno wyrokować o przyczynach takiego stanu rzeczy. Kernerówna i Sperling prawdopodobnie wolały wystawiać poza auspicjami organizacji. Weingrünówna funkcjonowała zarówno w środowisku żydowskim, jak i nieżydowskim. Landau-Eigerowa i Nebenzahl-Wistreich po wyjściu za mąż mogły być pochłonięte życiem rodzinnym i dlatego ograniczyły udział w wystawach. Antonina Richter mieszkała poza Krakowem i mogła nie być zainteresowana utrzymywaniem kontaktów z organizacją. Helena Grabschrift z powodu choroby zawiesiła na pewien czas studia na Akademii Sztuk Pięknych i ze Zrzeszeniem związała się dopiero w 1938 r., jednak od razu włączyła się w jego działalność z dużą aktywnością. Fryderyka Sternberg-Fenichlowa była zmuszona po studiach podjąć pracę zarobkową, trudno jednak ocenić, czy właśnie ta okoliczność wpłynęła na jej małą aktywność na scenie artystycznej. Dwudziestoletnia Lewkowiczówna w 1938 r. dopiero zaczynała karierę - nie wiadomo, jak potoczyłyby się jej dalsze losy. Z dorobku Matzner-Abelesowej i Zollmanówny, które brały udział wyłącznie w wystawach Zrzeszenia, nic nie ocalało, nie ma zatem możliwości się zorientować, czy w ogóle dysponowały pracami pozwalającymi im zaistnieć w środowisku innym niż żydowskie, które współtworzyły z racji pochodzenia. 
motywującego tekstu była przemyśleniami autora na temat trudów, jakim musi podołać artysta, aby zrealizować swoje cele, nie schodząc przy tym na manowce i nie ulegając pokusie schlebiania gustom publiczności czy naporowi zewnętrznych okoliczności odbierających chęć i wiarę w sens pracy. Autor, który był również poetą, porównywał Weingrünównę do kwiatu w doniczce - „bardzo czułego, bardzo potrzebującego ciepła” i przestrzegał ją, żeby nie dawała się zrazić komentarzami, że zamiast tego jeszcze nie raz północ będzie w nią „mrozem dmuchać” albo że „talent nie daje chleba” ${ }^{50}$.,Kochana koleżanko - to nieprawda”, pisał. „Zatem tylko nie dać się ugiąć", konkludował swoje przestrogi ${ }^{51}$. Idealistyczna postawa w stosunku do kobiet, którą ujawnił Schinagel chociażby wspomnianym porównaniem koleżanki do kwiatu, nie jest czymś, co zaskakiwałoby w przypadku tego autora, jeśli weźmiemy pod uwagę całokształt jego działalności i praktyki zawodowej. Lekarz pediatra, autor podręcznika dotyczacego opieki nad niemowlętami, był też jedną z osób najbardziej zaangażowanych w Krakowie w latach trzydziestych w akcję na rzecz świadomego macierzyństwa i tak zwanej reformy seksualnej. Przejmował się nie tylko losem matek obciążonych gromadką dzieci, ale również kobiet, które życie pchnęło w kierunku prostytucji. Bardzo zaangażowany i jednocześnie emocjonalny prawdopodobnie bardziej niż inni uciekał przed naporem prozy życia w świat poezji i idealistycznych wyobrażeń ${ }^{52}$. Wydaje się, że sposób, w jaki pisał o koleżance, świadczy przede wszystkim o nim samym i nie był raczej ugruntowaną wśród członków Zrzeszenia postawą wobec artystek związanych z organizacją.

Prawdopodobnie do bardziej miarodajnej odpowiedzi na pytanie o poglądy członków Zrzeszenia dotyczące dorobku artystycznego kobiet i ich aktywności zawodowej na tym polu przybliżałby nas tekst Henryka Webera opublikowany w „Nowym Dzienniku” w 1934 r. - jedyna wypowiedź w ciągu ośmiu lat istnienia organizacji wprost odnosząca się do poruszanej tu problematyki. Okazji po temu dostarczyła prezentacja dorobku Gizeli Nebenzahl-Wistreichowej w ramach Zrzeszenia. Zainspirowała ona

${ }^{50}$ Emil Schinagel, Udany debiut. Z wystawy w Żydowskim Domu Akademickim, „Nowy Dziennik” (1933), nr 110, s. 6.

${ }^{51}$ Tamże.

${ }^{52}$ Zob. Natasza Styrna, Emil Schinagel, artysta, lekarz, społecznik, [w:] Księga pamiatkowa dedykowana profesorowi Tomaszowi Gryglewiczowi, red. Jan Ostrowski, Andrzej Szczerski, Marek Walczak, Marek Zgórniak [w druku]. Tomik poezji Schinagel opublikował pod pseudonimem: Emil Romanda, Bunt ziemi, Warszawa 1928. Zob. też: Emil Szinagel, Pielęgnowanie niemowląt. Przewodnik dla matek i pielęgniarek, Kraków 1938. 
Henryka Webera do uwag, które rzucają sporo światła na sposób, w jaki odnoszono się do działalności koleżanek w kręgu osób związanych ze Zrzeszeniem. Rozważania dotyczyły rzekomo odrębnego charakteru twórczości kobiet, obecności w niej tak zwanego kobiecego pierwiastka. Krytyk podszedł do tego zagadnienia z dużą dozą sceptycyzmu, co mogło wyrażać jego własne stanowisko, ale mogło też być częstszą postawą w środowisku, które reprezentował. „Mam wrażenie - pisał - że gdybyśmy przyjęli serio pewien schemat »malarstwa męskiego i malarstwa kobiecego «, uzyskalibyśmy drażliwe zamieszanie i mógłbym, już z miejsca, podać nazwiska »pewnych mężczyzn «, którzy znaleźliby się w malarskim »oddziale dla kobiet «"53. Swoją opinię krytyk uzasadniał przykładami „mocarnych, surowych, konstruktywistycznych motywów", z którymi zetknął się w swojej karierze, „które na długie metry biły »wyrazem męskim «”, a w rzeczywistości okazywały się pracami kobiet ${ }^{54}$. Wskazywał też na inne zagrożenie - tworzenie teorii ex post, doszukiwanie się na siłę czegoś kobiecego w pracach artystek, gdy już dowiemy się, że wyszły one spod ręki kobiety, na przykład „szczególnej miękkości czy też koronkowych zarysów kształtów"55. Stwierdzał, że on sam w takim razie, „na przekór”, znajduje w pracach Gizy Wistreich cechy męskie ${ }^{56}$. Miał na myśli zapewne przymiotniki, jakie mu się nasuwały na określenie twórczości artystki, która swym obfitym dorobkiem wypełniła całą jedną salę wystawowa - „dobry i silny” obraz czy „mocne, zdecydowane w kolorze" uderzenia pędzlem ${ }^{57}$.

Co ciekawe, ten trzeźwo myślący krytyk (który podobnie jak Schinagel był również poetą), niejednokrotnie wykazujący się sceptycyzmem, nie zawsze konsekwentnie dawał w pisanych tekstach wyraz teoriom, które głosił. Przywołać tu można chociażby wspomniane wypowiedzi na temat Kernerówny, która absolutnie zachwycała Webera, nie wyłączając dostrzeganej w jej pracach „potęgi kobiecości” - „Gigantentum ihrer Weiblichkeit", jak powtarzał za jej nauczycielem Antonem Hanakiem ${ }^{58}$ i wyjaśniał:

Mowa tu o owym gigantyzmie, który grozę zamknie w kamei, dziwność uśmierzy formą naszyjnika. Który świętość umieszcza w łagodnej niszy domostwa, a kul-

${ }^{53}$ Henryk Weber, Wystawa „Zrzeszenia”...

54 Tamże.

55 Tamże.

${ }_{56}$ Tamże.

${ }^{57}$ Prawie zupełnie nieznaną dzisiaj malarkę krytyk chwalił również za dużą wrażliwość i temperament kolorystyczny. Tamże.

${ }_{58}$ Weber, Na wysepce majolikowej... 
towi daje macierzyński cień i jasny połysk ciała. W szlachetnej sztuce Henryki Kernerówny ta siła istnieje. Włada tu jak owa cicha ręka kobieca, która koronką zdobniczą oplata wieki, trwały swój ślad na folklorze haftuje, a wielką prawdę sztuki w dyskretnym geście palców zamyka ${ }^{59}$.

Takie kwieciste formy wypowiedzi, zdradzające pełen atencji stosunek do autorek prac, jak zacytowana powyżej opinia Webera na temat Kernerówny czy słowa Schinagla skierowane do Anny Weingrün, pojawiały się jednak stosunkowo rzadko w recenzjach dorobku artystek Zrzeszenia. Znacznie częściej można odnieść wrażenie, że udział kobiet we wspólnych przedsięwzięciach był dla pozostałych członków Zrzeszenia po prostu czymś naturalnym, oczywistym. Jednocześnie nie wydaje się, aby poddawano jakiejś głębszej refleksji sytuację kobiet w świecie sztuki czy to w kontekście możliwości samostanowienia o sobie, podejmowania edukacji, posiadania własnej pracowni, zarobkowania, czy też konsekwencji społecznych albo rodzinnych ponoszonych przez kobiety wkraczające na ścieżkę kariery artystycznej i dążące do samorealizacji w tym zakresie. Była to po prostu część szerszego procesu, który umykał być może refleksji członków Zrzeszenia chociażby dlatego, że w latach trzydziestych coraz więcej uwagi i energii pochłaniała potrzeba radzenia sobie z rozmaitymi konsekwencjami pogłębiającego się antysemityzmu, od ekonomicznych poczynając, na psychicznych i emocjonalnych kończąc. Zjawisko to uderzało pospołu w mężczyzn i kobiety związane ze Zrzeszeniem. Najprawdopodobniej uznano, że bariery w postaci niemożności podjęcia nauki w niektórych uczelniach artystycznych zostały usunięte i obecnie sytuacja kobiet w żaden szczególny sposób nie różni się od sytuacji mężczyzn mogą i będą robić to samo, co do tej pory robili mężczyźni. Na refleksję, że potrafią w obszar sztuki wnieść nowe, własne, nieco inne doświadczenia, zainteresowania, inaczej porozkładać akcenty, podejmując nawet te najbardziej utarte wątki tematyczne, było prawdopodobnie za wcześnie.

\section{Członkinie Zrzeszenia na scenie artystycznej Krakowa}

Aby uzupełnić obraz, który się tutaj rysuje, warto również się przyjrzeć postrzeganiu kobiet tworzących Zrzeszenie nie tylko przez najbliższy krąg osób związanych z organizacją, ale również szerzej, wśród przedstawicieli pozostałej części środowiska artystycznego w Krakowie. Niestety 
nie ma zbyt wielu przydatnych informacji, które pozwoliłyby przybliżyć to zagadnienie $^{60}$. Z jednej strony wiadomo, że Jadwiga Sperling z większym powodzeniem niż w żydowskich kręgach artystycznych funkcjonowała w środowisku nieżydowskim, chętniej wystawiała z członkami „Zwornika” niż Zrzeszenia. Anna Weingrün współtworzyła grupę „Prąd”, Antonina Richter - grupe „Ster” we Lwowie. Kernerówna nie tylko sporo wystawiała, ale spotykała się też z bardzo przychylnymi reakcjami krytyków na łamach rozmaitych periodyków, nie tylko żydowskich. Starsze artystki ze Zrzeszenia generalnie chętnie wystawiały poza ramami organizacji. Z kolei najmłodsze członkinie, które przyłączyły się do organizacji niedługo przed wojną, ograniczały się wyłącznie do udziału w wystawach Zrzeszenia. Rodzi się pytanie: dlaczego? Czy gęstniejąca sytuacja przed wojną, rosnące napięcia społeczne i polityczne, zmęczenie sytuacją miały na to wpływ?

Trudno rozstrzygnąć tę kwestię, ale można przynajmniej spróbować zarysować sytuację, w jakiej w latach trzydziestych przyszło działać i tworzyć artystkom ze Zrzeszenia. Warte przytoczenia jest szczególnie jedno, dość głośne w Krakowie wydarzenie, które może dawać pewne wyobrażenie, jak odnoszono się do ich aktywności na scenie artystycznej. Cztery z nich - Weingrün, Landau, Sperling i Nebenzahl - oprócz Zrzeszenia Żydowskich Artystów należały również do Zawodowego Związku Polskich Artystów Plastyków. Wiosną 1934 r. wzięły udział w wystawie zainicjowanej przez członków organizacji, urządzonej z okazji osiemdziesięciolecia Towarzystwa Przyjaciół Sztuk Pięknych (TPSP). Imprezę pomyślaną jako wielka ogólnopolska prezentacja dorobku współczesnych polskich twórców inaugurowano z wielką pompą, w wernisażu uczestniczył Prezydent Rzeczypospolitej Polskiej Ignacy Mościcki. Szybko się jednak okazało, że wydarzenie nie spełniło pokładanych w nim nadziei. Głosy krytyczne płynęły z różnych stron, lecz najbardziej niezadowoleni byli młodzi artyści, których pominięto przy podziale nagród, rozdzielając większość laurów między przedstawicieli starszej generacji, w tym „organizatorów

${ }^{60}$ Mimo że wystawy w Żydowskim Domu Akademickim nie cieszyły się dużym zainteresowaniem poza środowiskiem żydowskim, od czasu do czasu pojawiały się na nich prominentne osobistości spoza kręgów żydowskich. Należał do nich Feliks Kopera, dyrektor Muzeum Narodowego, który w początkowej fazie istnienia organizacji z dużą częstotliwością gościł na imprezach organizowanych przez członków i członkinie Zrzeszenia. Ich działania starał się również wspierać, kupując od nich podczas wernisaży obrazy do kolekcji muzealnej. Niestety na stronach „Nowego Dziennika” nie zachowała się informacja, aby kiedykolwiek wybrał pracę kobiety. W zbiorach Muzeum Narodowego znajduje się obraz Jadwigi Sperling, nie wiadomo jednak, czy trafił do nich z wystawy Zrzeszenia Żydowskich Artystów. 
»Salonu 1934«, profesorów Akademii Sztuk Pięknych, a nawet członków jury”, co również nie umknęło uwagi ${ }^{61}$. Nie godząc się z taką sytuacją, kilka dni po ogłoszeniu wyników młodzi twórcy przybyli do Pałacu Sztuki i demonstracyjnie zaczęli ściągać swoje obrazy ze ścian, po czym urządzili własną, niezależną wystawę w lokalu Zawodowego Związku Polskich Artystów Plastyków przy pl. św. Ducha 5, ogłaszając jednocześnie bojkot TPSP. Oprócz Jana Cybisa, Józefa Czapskiego, Czesława Rzepińskiego, Jacka Pugeta czy Wacława Taranczewskiego w wydarzeniach brały udział również cztery wyżej wymienione artystki. Łącznie do bojkotu przyłączyło się czterdzieści osób. Skład tego grona budzi zainteresowanie z uwagi na dalszy rozwój wypadków. Dziesięcioro osób wywodziło się ze środowiska żydowskiego, z czego dziewięcioro było związanych z krakowskim Zrzeszeniem Żydowskich Artystów. Kobiet w tym gronie było również dziesięć, czyli stanowiły jedną czwartą grupy artystów, którzy podjęli najbardziej zdecydowane kroki w związku z niesprawiedliwym, jak uważali, potraktowaniem przez jury. Rozpoczętą akcję, jak można przeczytać na łamach „Głosu Plastyków”, w kolejnych dniach miało poprzeć solidarnie ponad czterystu artystów. Nie znaczy to jednak, że secesjoniści spotkali się z powszechnym poparciem czy zrozumieniem. Dość ostro zaatakowano ich na łamach „Sztuk Pięknych”, wprost im zarzucając nazbyt wygórowane, niewspółmierne do ich dotychczasowych osiągnięć ambicje oraz niestosowność zabierania głosu w sprawie przyznawania nagród z uwagi na wspomniane nieduże doświadczenie ${ }^{62}$. Jest to jeden z najciekawszych wątków w relacjonowanym sporze. Rzecz bynajmniej nie polega na próbie jego rozstrzygnięcia, istotniejszy z powodu tematyki poruszanej w niniejszym opracowaniu jest dobór nazwisk, którym posłużył się anonimowy autor „Sztuk Pięknych”, żeby zdyskredytować grono młodych twórców roszczących sobie - jego zdaniem - nieuzasadnione pretensje. Wśród pięciorga osób znalazł się tylko jeden mężczyzna, Żyd, Józef Badower. Oprócz niego autor wymienił cztery kobiety, pragnąc zilustrować absurdalność, w jego opinii, oczekiwania na nagrodzenie wyników pracy. $\mathrm{Na}$ pierwszym miejscu znalazła się „panna Landauówna”, w przypadku której autor czuł potrzebę zaznaczenia, że artystka była niezamężna nie tylko końcówką nazwiska, ale podwójnym wyeksponowaniem tego faktu. Być

${ }^{61}$ „Głos Plastyków” (1934), nr 9-12, s. 172; „Sztuki Piękne” 10 (1934), nr 6, s. 230-231; Maria Liczbińska, Wydarzenia artystyczne w kraju (1934), [w:] Polskie życie artystyczne w latach 1915-1939, red. Aleksander Wojciechowski, Wrocław 1974, s. 323-325.

62 „Sztuki Piękne” 10 (1934), nr 6, s. 231. 
może chciał w ten sposób stworzyć wrażenie, że pod listem protestacyjnym podpisała się osoba bardzo młoda, która jeszcze niewiele potrafi. Anna Landau miała wówczas trzydzieści lat i ukończone studia artystyczne, lecz czytając „panna Landauówna”, rzeczywiście można było odnieść wrażenie, że chodzi o kogoś zupełnie początkującego. Ponadto, do nazwisk Badowera i Landau autor dołączył kolejną Żydówkę, Annę Weingrün, oraz dwie inne artystki - Hannę Krzetuską i Annę Szyszko-Bochusz Szymborską. Biorąc pod uwagę artystów, którzy wzięli udział w bojkocie, w tej wyliczance rzekomo nadmiernie roszczeniowych osób znajdujemy rzucającą się w oczy nadreprezentację kobiet, jak również przedstawicieli mniejszości żydowskiej. Autor mógł mieć rację, robiąc każdej z tych osób zarzut z dość jeszcze skromnych osiągnięć na scenie artystycznej. Problem dotyczył jednak większej części sygnatariuszy protestu. Pomijając tę okoliczność, autor z jakiegoś powodu uznał za stosowne ostrze krytyki skierować przede wszystkim do kobiet, a w drugiej kolejności - do Żydów.

Zdarzenie daje wyobrażenie o sytuacjach, z jakimi mogły mierzyć się artystki ze Zrzeszenia być może nie na co dzień, lecz niewątpliwie z pewną częstotliwością. Oprócz afrontów czynionych im z powodu pochodzenia musiały sobie radzić również z uprzedzeniami, które dotykały je z powodu płci. Nie każdy atak musiał być frontalny, ale te bardziej zakamuflowane jak w powyższym przykładzie - były zapewne nie mniej bolesne. Znalazły się naprawdę w trudnej sytuacji - jako kobiety i Żydówki miały zaledwie krótką chwilę, żeby zaistnieć na polskiej scenie artystycznej. Ledwo udało im się skruszyć trudne do sforsowania mury krakowskiej Akademii, czas, jaki im pozostał, żeby się wybić i zrealizować swoje plany, okazał się dość krótki - najwyżej kilkanaście lat w przypadku tych, które zaczęły studia wcześniej. Wiek artystek, a co za tym idzie - czas, jaki miały do dyspozycji, aby osiągnąć jakąś pozycję w świecie sztuki, miały w tej szczególnej sytuacji kluczowe znaczenie. Udowadnia to przykład Kernerówny, która jako nieco starsza od pozostałych zdążyła mieć swoje chwile brylowania i sukcesów na scenie artystycznej. Ale nawet w jej przypadku dowiedzenie się czegoś więcej o niej, dotarcie do jej dorobku, nastręcza wiele trudności. W 1937 r. artystka wzięła udział w Międzynarodowej Wystawie Sztuki i Techniki w Paryżu, a rok później w prezentacji współczesnej sztuki kościelnej w Luwrze. Kontakty nawiązane w środowisku paryskim prawdopodobnie ocaliły jej życie, bo właśnie tam wyjechała na początku wojny. Datę jej śmierci, 1978 rok, długo nieznaną, ustaliła Bożena Kostuch z Muzeum Narodowego w Krakowie. 


\section{Zakończenie}

Można powiedzieć, że po artystkach współtworzących przed wojną krakowskie Zrzeszenie Żydowskich Artystów właściwie przepadł ślad. Jeśli słuch zaginął po tak stosunkowo popularnej rzeźbiarce, jaką była Henryka Kernerówna, można sobie wyobrazić, jaki jest stan wiedzy na temat pozostałych. Po niektórych nie pozostała nawet wzmianka w najdokładniejszych słownikach biograficznych polskich twórców, zdarzały się przypadki informowania o śmieci żyjących artystek, o losach niektórych nadal nic nie wiadomo. Sytuację utrudniały wyrosłe po wojnie nowe mury i granice. Nie mniejszą barierę utworzyła trauma tych, które przeżyły i nie chciały w żaden sposób wracać do tego, co łączyło je z krajem i dawnym życiem. A wojnę, wbrew temu, co można by przypuszczać, znając los Żydów polskich, przeżyła większość wymienionych tu artystek. Jednak żadna z nich nie związała swojej przyszłości z Polską.

Anna Landau-Eigerowa (zm. 1999) cudem uniknęła śmierci we Lwowie z rąk radzieckiego żołnierza, który ją postrzelił i zabił jej kuzynkę, żeby zrabować im zegarki ${ }^{63}$. Po wojnie zamieszkała w Rio de Janeiro. Jej przyjaciółka Anna Weingrün, po mężu Lieblich (zm. 1997), w czasie wojny przebywała w Rosji, gdzie utrzymywała się z nauczania malarstwa. W 1950 r. wyemigrowała z Polski do Izraela. Była bardzo aktywna na scenie artystycznej, współtworzyła kolonię artystyczną w Safed. Dwukrotnie, w roku 1952 i 1977, otrzymała izraelską nagrodę im. Hermana Strucka ${ }^{64}$. Jadwiga Sperling wyszła za mąż za serbskiego malarza Milana Cetîca, którego poznała na Akademii Sztuk Pięknych w Krakowie, i wyjechała do Belgradu (zm. 1978). Gizela Nebenzahl-Wistreich została zamordowana w 1942 r., taka sama data śmierci widnieje przy nazwisku jej syna Romana, męża zamordowano rok później ${ }^{65}$. Miejsce jej śmierci jest nieznane, według jej brata Zygmunta Nebenzahla widziano ją z dzieckiem

${ }^{63}$ List Aliny Dankowicz z 22 października 2006 r., w posiadaniu autorki.

${ }^{64}$ Anna Lieblich Weingrun, Information Center for Israeli Art, https://museum.imj. org.il/artcenter/newsite/en/?artist=Lieblich\%20Weingrun,\%20Anna [dostęp: 24 września 2021].

${ }^{65}$ Giza Gisella Wistreich (Nebenzahl), https://www.geni.com/people/Giza-Gisella-Wistreich/6000000069325460834; Roman Wistreich, https://www.geni.com/people/Roman-Wistreich/6000000069325381927; Dr. Bernhard Wistreich, https://www.geni.com/people/ Dr-Bernhard-Wistreich/6000000069325600823; The Central Database of Shoah Victims' Names, Yad Vashem, https://yvng.yadvashem.org/index.html?language $=$ en\&s_id $=\&$ s lastName $=$ wistreich\&s_firstName $=$ roman $\&$ s_place $=\&$ s_dateOfBirth $=\&$ cluster $=$ true [dostęp: 27 lutego 2021]. 
w warszawskim getcie ${ }^{66}$. Przed wojną artystka brała udział w wystawach, jej dorobek chwalono na łamach prasy, jednak w żadnym ze świadectw na temat jej śmierci złożonych w Yad Vashem przez członków najbliższej rodziny nawet nie wspomniano, że była malarką. Szwagier Mordechaj Wistreich określił ją mianem gospodyni domowej ${ }^{67}$. Być może w obliczu tragedii, jaką była śmierć całej rodziny, wydawało się mało istotne, czym się zajmowała. Jednocześnie żadna z osób zeznających w sprawie śmierci jej męża nie pominęła jego zawodu.

Najprawdopodobniej zamordowano również Ernestynę Zollman. Ostatni znaleziony ślad po niej to protokół z akcji wysiedlania Żydów z Krakowa z sierpnia 1940 r. (zob. il. 6). W rubryce zawód ponownie znalazła się informacja, że jest artystką malarką, obok dopisano: „pomocnica krawiecka" ${ }^{68}$. Deklarując użyteczne umiejętności, artystka prawdopodobnie miała nadzieję na zwiększenie swoich szans na przeżycie. W tym samym czasie z Krakowa wysiedlono również Fryderykę Sternberg-Fenichlową (il. 6). W protokole zapisano, że pełniła funkcję dyrektorki szkoły ${ }^{69}$. W 1943 r. artystkę zastrzelono w Bronowicach Małych ${ }^{70}$.

Antonina Richter (Tova Richter-Rauch, zm. 1992) podobnie jak Anna Weingrün kontynuowała po wojnie karierę w Izraelu. Brała udział w wielu wystawach, oprócz portretów malowała znakomite pejzaże. Hanka Lewkowiczówna znalazła się w czasie wojny w Kazachstanie, nigdy nie wróciła do kraju. Wyszła za mąż i zamieszkała w Moskwie, poświęciła się przede wszystkim baletowi ${ }^{71}$. Historia Heleny Grabschrift okazała się naprawdę zaskakująca. Przez ponad siedemdziesiąt lat artystka uchodziła za osobę, która zginęła w czasie wojny. W istocie była najdłużej żyjącą członkinią Zrzeszenia Żydowskich Artystów. Przeszła przez krakowskie getto i obóz w Płaszowie. Uciekła stamtąd i wraz z mężem Henrykiem Taffetem przedostała się do Palestyny. Później musiała się jeszcze zmierzyć z tragedią, jaką była śmierć dziecka. Malowała, lecz nie była aktywna na scenie artystycznej

${ }^{66}$ Roman Wistreich, [w:] tamże, https://yvng.yadvashem.org/nameDetails.html?languag e $=$ en\&itemId=1228951\&ind =1; Gisella Wistreich, [w:] tamże, https://ynng.yadvashem.org/ nameDetails.html?language $=$ en\&itemId=1936836\&ind $=1$ [dostęp: 27 lutego 2021].

${ }^{67}$ Giza Wistreich, [w:] tamże, https://yvng.yadvashem.org/nameDetails.html?language $=$ en\&itemId $=521466 \&$ ind $=1$ [dostęp: 27 lutego 2021].

${ }^{68}$ Ankiety personalne osób skierowanych do wysiedlenia z Krakowa, Centralna Biblioteka Judaistyczna, sygn. 218/34/261/27.

${ }^{69}$ Tamże, sygn. 218/34/49/72.

${ }^{70}$ Abba Fenichel. Krótka informacja biograficzna oraz na temat twórczości patrona skwe$r u$, http://edziennik.rzeszow.uw.gov.pl, zalacznik1.pdf [dostęp: 20 września 2021].

${ }_{71}$ Informacje o losach artystki przekazali mi jej siostra Ruth Goldberger oraz siostrzeniec Ari Goldberger. 

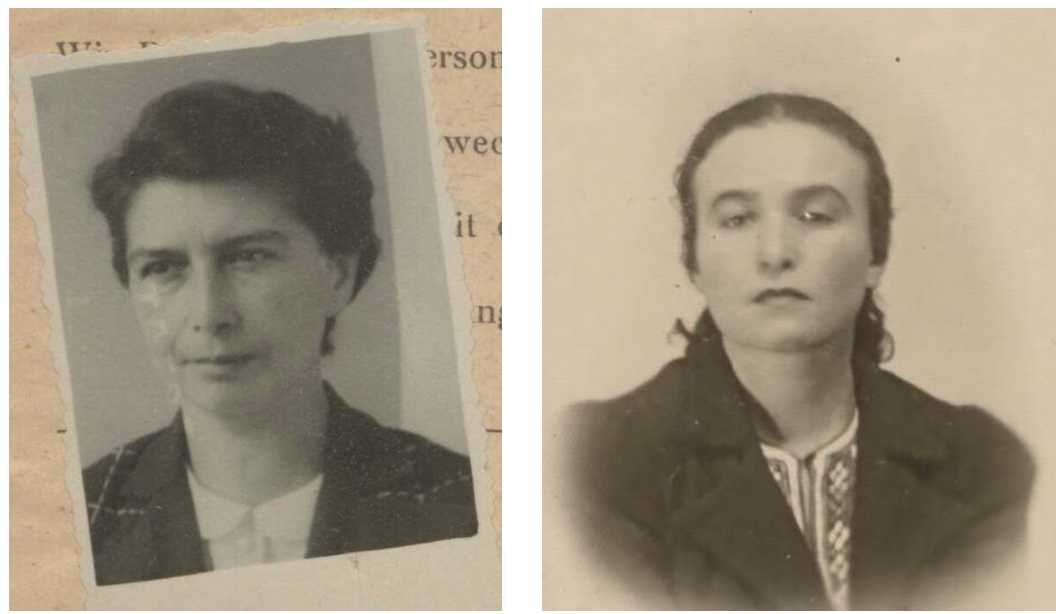

Il. 6. Ernestyna Zollman i Fryderyka Sternberg-Fenichlowa, fotografie z ankiet personalnych osób skierowanych do wysiedlenia z Krakowa, sierpień 1940, Centralna Biblioteka Judaistyczna.

w Izraelu - to, przez co przeszła, okazało się zbyt przytłaczające. Bezdzietna, po śmierci męża trafiła do domu opieki, gdzie zmarła w 2002 r. ${ }^{72}$

Trudno oprzeć się refleksji, że krakowskim Żydówkom zbyt dużo stanęło na przeszkodzie, aby mogły rozwinąć skrzydła na scenie artystycznej, zaistnieć, wypowiedzieć się w pełni. Najpierw musiały sforsować bariery dotyczące edukacji, później nadal zmagały się ze stereotypami dotyczącymi płci, w końcu ich życie znalazło się w bezpośrednim zagrożeniu. Te, które przeżyły, mogły i chciały kontynuować karierę artystyczną, zrobiły to daleko poza granicami Polski. W ich rodzinnym mieście ich nazwiska pozostają nieznane.

Nasuwa się gorzki wniosek, że niektóre z nich urodziły się za wcześnie, żeby móc w pełni partycypować w życiu środowiska artystycznego - zdobyć odpowiednie wykształcenie i skorzystać z możliwości, jakie ono daje. Natomiast pozostałe urodziły się zbyt późno, gdy - co prawda - formalne ograniczenia stojące na drodze kariery artystycznej kobiet przestały już funkcjonować, jednak czas, jaki im pozostał, aby zrealizować się zawodowo, przynajmniej w kraju, gdzie się urodziły, okazał się zbyt krótki. Ich losy pokazały dobitnie, że po wojnie ani w Krakowie, ani w Polsce nie było już dla nich miejsca. Żadna z nich nie wróciła na stałe. Anna Weingrün,

${ }^{72}$ Zob. Styrna, Helena Grabschrift-Taffet..., s. 22. 
która po wojnie na krótko znalazła się w Krakowie, wyjechała z kraju szybko i na zawsze.

Czas ich aktywności zawodowej przypadł na niezwykle trudną dekadę, która zakończyła bezpowrotnie historię żydowskiego środowiska artystycznego w Polsce. Te, które przeżyły, korzystały z doświadczenia nabytego w Krakowie w miejscach rozsianych od Moskwy po Rio de Janeiro.

\title{
Bibliografia
}

\section{1. Źródła archiwalne}

Archiwum Akademii Sztuk Pięknych w Krakowie, sygn. A5, sygn. A78, T21B, sygn. A79, T20B, sygn. A122, KS12 (1919/1920).

Archiwum Narodowe w Krakowie, sygn. StGKr 247, sygn. StGKr 848, sygn. StGKr 1047.

Biblioteka Akademii Sztuk Pięknych w Krakowie, sygn. 6431.

Centralna Biblioteka Judaistyczna, sygn. 218/34/261/27, sygn. 218/34/49/72.

Instytut Sztuki Polskiej Akademii Nauk, Zbiory specjalne, nr inw. 1776/II.

Narodowe Archiwum Cyfrowe, Zespół: Koncern Ilustrowany Kurier Codzienny Archiwum Ilustracji, sygn. 1-K-3516.

Zbiory Ruth Goldberger: Hanka Lewkowicz, Dzieci na wystawie, wycinek prasowy z 1939 r.; Hanka Lewkowicz, Mali talmudyści, fotografia.

\section{2. Źródła opublikowane}

\section{Czasopisma}

„Głos Plastyków” 1934.

„Naprzód” 1926.

„Nowy Dziennik” 1929-1939.

„Przegląd Artystyczny” 1936.

\author{
„Rzeczy Piękne” 1930. \\ „Sygnały” 1939. \\ „Sztuki Piękne” 1930, 1934. \\ „Światowid" 1934.
}

\section{Inne źródła drukowane}

A. H., Wystawa plastyk Henryki Kernerówny w Tow. Sztuk Pięknych w Krakowie, „Naprzód” (1926), nr 97.

Henryka Kernerówna, „Światowid” (1934), nr 52.

Materiały do dziejów Akademii Sztuk Pięknych w Krakowie 1895-1939, oprac. Józef E. Dutkiewicz, Jadwiga Jeleniewska-Ślesińska, Władysław Ślesiński, Wrocław 1969.

Pajek Maria, Katalog rzeźb, obiektów przestrzennych i medali z kolekcji Centrum Rzeźby Polskiej w Orońsku, Orońsko 2013.

Schinagel Emil, Udany debiut. Z wystawy w Żydowskim Domu Akademickim, „Nowy Dziennik" (1933), nr 110.

Szafran Tadeusz, Prace ceramiczne Henryki Kernerówny, „Rzeczy Piękne” (1930).

Die Verlorene Moderne: Der Künstlerbund Hagen 1900-1938 (katalog wystawy), Österreichische Galerie Belvedere, Wien 1993. 
Weber Henryk, Na wysepce majolikowej (W atelier Henryki Kernerówny), „Nowy Dziennik" (1931), nr 145.

Weber Henryk, Wystawa ceramik Henryki Kernerównej w Tarnowie, „Nowy Dziennik” (1931), nr 166.

Weber Henryk, Wystawa rzeźb i ceramiki Hanki Lewkowiczówny, „Nowy Dziennik” (1938), nr 340.

Weber Henryk, Wystawa „Zrzeszenia”, „Nowy Dziennik” (1934), nr 22.

Ygrek, Wieczór tańców Hanki Lewkowiczówny, „Nowy Dziennik” (1939), nr 120.

\section{Opracowania}

Demko Iwona, Zofia Baltarowicz-Dzielińska, pierwsza studentka Akademii Sztuk Pięknych w Krakowie, Kraków 2018.

Janczyk Agnieszka, Fromowiczowie - portret rodziny, „Krzysztofory” 35 (2017).

Janczyk Agnieszka, „Polacca di nascita ed Italiana di adozione” - malarka Maria

Fromowicz (1897 - po 1969). Próba uporządkowania biografii, [w:] Wędrowanie

sztuki, red. Artur Badach, Katarzyna Chrudzimska-Uhera, Warszawa 2018.

Kaszuba-Dębska Anna, Bruno. Epoka genialna, Kraków 2020.

Kołodziejowa Bolesława, Ceramika krakowska I poł. XX wieku, „Rocznik Muzeum Mazowieckiego w Płocku” 14 (1991).

Liczbińska Maria, Wydarzenia artystyczne w kraju (1934), [w:] Polskie życie artystyczne w latach 1915-1939, red. Aleksander Wojciechowski, Wrocław 1974.

Piątkowska Renata, Studenci wyznania mojżeszowego w warszawskiej Akademii Sztuk Pięknych (1923-1939). Studia - debiuty - kariery, „Biuletyn Historii Sztuki” (2015), nr 4.

Ruta Zygmunt, Prywatne szkoły średnie ogólnokształcace w Krakowie $i$ województwie krakowskim w latach 1932-1939, Kraków 1990.

Samozwaniec Magdalena, Maria i Magdalena, Kraków 1956.

Schönker Henryk, Dotknięcie anioła, Warszawa 2005.

Sosnowska Joanna, Poza kanonem. Sztuka polskich artystek 1880-1939, Warszawa 2003.

Starzewska Maria, Polska ceramika artystyczna pierwszej połowy XX wieku, Wrocław 1952.

Styrna Natasza, Helena Grabschrift-Taffet, krakowska artystka urodzona w Tuchowie, „Folia Historica Cracoviensia” 27 (2021), z. 1.

Styrna Natasza, Zrzeszenie Żydowskich Artystów Malarzy i Rzeźbiarzy w Krakowie 1931-1939, Warszawa 2009.

Trześniowski Dariusz, „A trwanie twoje jest jak śmierć, na zawsze - coraz straszniejsze i krwawsze”. Modernistyczny wizerunek Salome, „Pamiętnik Literacki” (2001), z. 1.

Weiss Zofia, Łomnicka Katarzyna, Konstanty Laszczka, Kraków 2016.

Natasza Styrna

Instytut Historii Sztuki i Kultury Uniwersytet Papieski Jana Pawła II w Krakowie nataszastyrna@poczta.fm 
